\title{
Justifying phytogenic feed additive matrix values in conjunction with exogenous feed enzymes
}

\author{
Laurel K. Shires \\ West Virginia University
}

Follow this and additional works at: https://researchrepository.wvu.edu/etd

\section{Recommended Citation}

Shires, Laurel K., "Justifying phytogenic feed additive matrix values in conjunction with exogenous feed enzymes" (2010). Graduate Theses, Dissertations, and Problem Reports. 3009.

https://researchrepository.wvu.edu/etd/3009

This Thesis is protected by copyright and/or related rights. It has been brought to you by the The Research Repository @ WVU with permission from the rights-holder(s). You are free to use this Thesis in any way that is permitted by the copyright and related rights legislation that applies to your use. For other uses you must obtain permission from the rights-holder(s) directly, unless additional rights are indicated by a Creative Commons license in the record and/ or on the work itself. This Thesis has been accepted for inclusion in WVU Graduate Theses, Dissertations, and Problem Reports collection by an authorized administrator of The Research Repository @ WVU. For more information, please contact researchrepository@mail.wvu.edu. 
Justifying Phytogenic Feed Additive Matrix Values in

Conjunction with Exogenous Feed Enzymes

Laurel K. Shires

Thesis submitted to the

Davis College of Agriculture, Natural Resources and Design

at West Virginia University

in partial fulfillment of the requirements for the degree of

\author{
Master of Science \\ in \\ Animal and Nutritional Sciences \\ Joseph S. Moritz, Ph.D., Chair \\ Kenneth Blemings, Ph.D. \\ Margaret Minch, D.V.M
}
Division of Animal and Nutritional Sciences
West Virginia University
Morgantown, West Virginia
2010

Key words: phytogenic additives, matrix values, exogenous enzymes, true amino acid digestibility 


\section{ABSTRACT \\ Justifying Phytogenic Feed Additive Matrix Values in Conjunction with Exogenous Feed Enzymes}

\section{Laurel K. Shires}

Phytogenic feed additives are purported to possess antimicrobial properties as well as nutrient sparing characteristics that may aid in alleviating high diet costs; however, in order for PFA's to assist nutritionists in decreasing diet cost, matrix values must be determined and implemented in feed formulation. Study 1 evaluated proposed matrix values for a commercially available PFA and assessed nutrient sparing when the product was combined with commercial phytase, carbohydrase and protease. The most remarkable proposed matrix values were $32.2 \mathrm{kcal} / \mathrm{kg}$ for metabolizable energy and $0.07 \%$ for both Ca and AP. The objective of Study 2 was to determine true amino acid digestibility (TAAD) and nitrogen corrected true metabolizable energy (TME $\mathbf{E}_{\mathbf{n}}$ ). Dietary treatments for both studies included a basal, basal with phytogenic product matrix value, basal with phytogenic product matrix value and phytogenic product, and similar treatments evaluating the phytogenic product matrix with exogenous enzyme products. Decreasing the basal diet by the proposed phytogenic matrix values decreased broiler live weight gain and increased feed conversion ratio $(\mathrm{P} \leq 0.05)$. However, when the same diet included the phytogenic feed additive, live weight gain and feed conversion ratio were restored to that of the basal diet $(\mathrm{P}>0.05)$. The proposed matrix values of the specific PFA tested were justified. However, the PFA was not additive or synergistic with exogenous enzymes. Nitrogen corrected true metabolizable energy and TAAD data did not differ when the diets varied based on the PFA per se $(\mathrm{P}>0.05)$. However, when the PFA was incorporated using proposed matrix values and used in conjunction with exogenous enzymes and their matrix values, $\mathrm{TME}_{\mathrm{n}}$ and several tested $\mathrm{TAAD}$ values were decreased $(\mathrm{P} \leq 0.05)$. Mechanistic speculation for decreased nutrient digestibility may perhaps involve reductions in gut microflora due to the PFA as well as simultaneous reduction in substrate concentrations. 


\section{Acknowledgements}

First and foremost, I would to thank my major professor and advisor, Dr. Joseph Moritz for encouraging me to further my education in the field of Animal Nutrition. Without his persistence, my academic career would have ended just two short years ago. I would also like to thank my committee members, Dr. Kenneth Blemings and Dr. Margaret Minch for taking the time to be a part of this process as well as the WVU faculty and staff. To all of my lab mates: I cannot thank you enough for the hard work and effort you have put into, not only your personal endeavors but into mine as well. Without you all, there would have been a lot more work and too few laughs. Lastly, I would like to thank my husband and family for their relentless support and guidance. 
TABLE OF CONTENTS PAGE

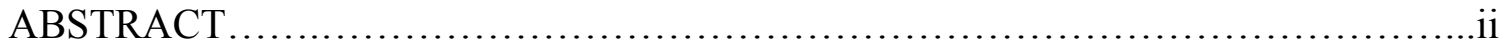

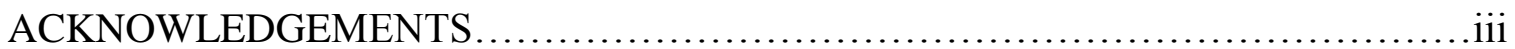

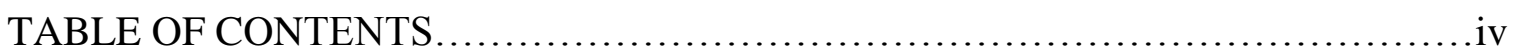

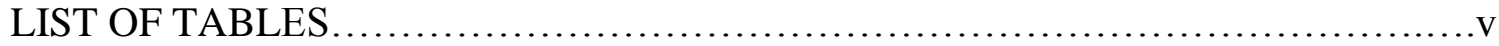

CHAPTER ONE- LITERATURE REVIEW ..........................................

Phytogenic Feed Additives......................................................

Antimicrobial Action and Improved Gut Function....................................

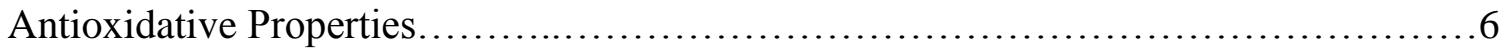

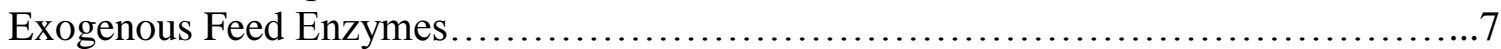

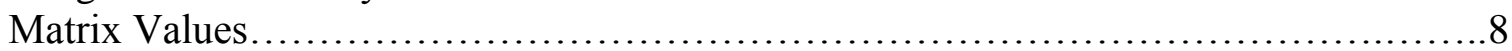

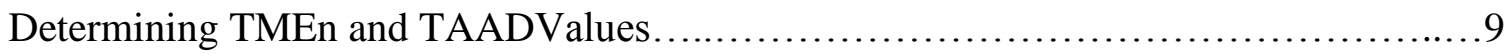

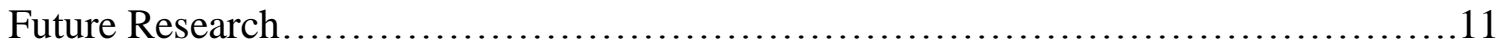

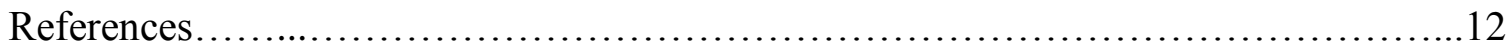

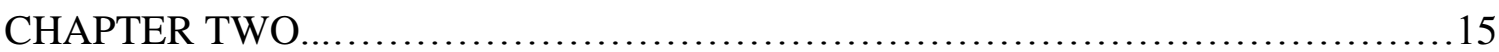

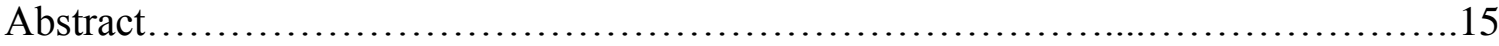

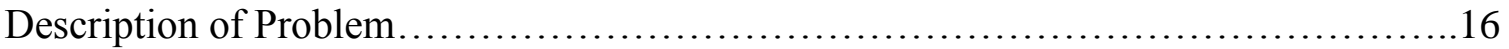

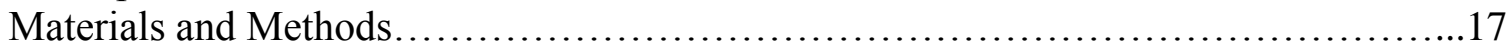

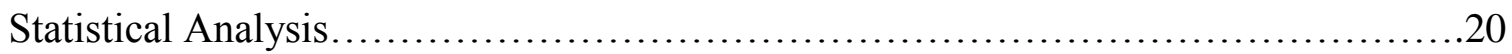

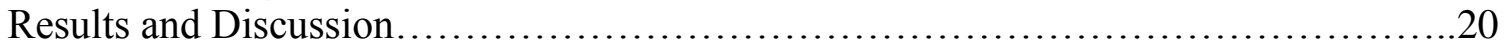

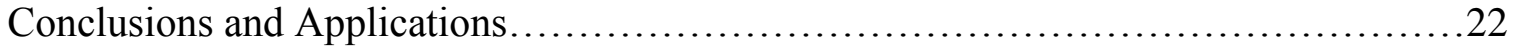

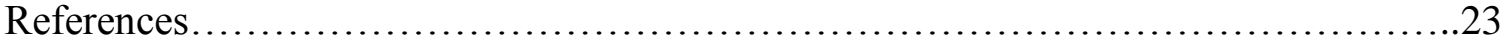

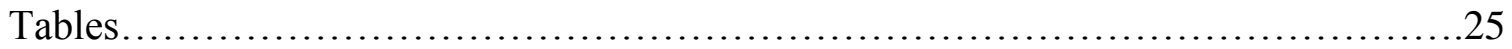

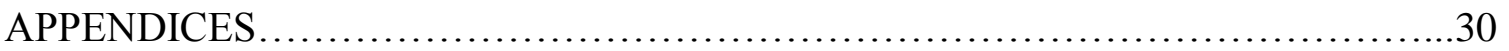

I. Proposal: Calcium and Phosphorus Sparing Efficacy of Diets Containing

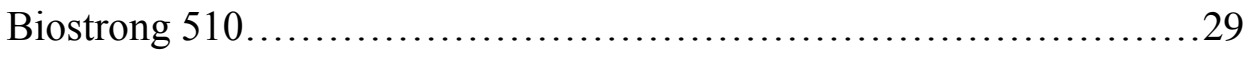

II. Matrix Value Justification of a Commericially Available Phytase.........32

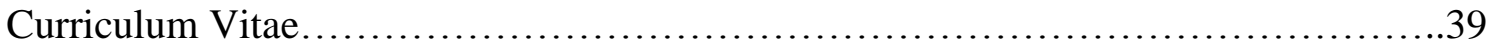




\section{LIST OF TABLES}

\section{CHAPTER TWO}

TABLE 1. Diet formulations for treatments 1-8 (Study 1 and 2)................25

TABLE 2. Performance data for 4-21-d broiler chickens (Study 1)..............27

TABLE 3. Cecectomized rooster $\mathrm{TME}_{\mathrm{n}}$ and TAAD values (Study 2 )..........28 


\section{LITERATURE REVIEW}

\section{PHYTOGENIC FEED ADDITIVES}

Recently, consumers have expressed growing concerns surrounding the possible development of antibiotic resistant bacteria resulting from excessive, low level use in livestock production. This has prompted the ban of numerous antibiotics in animal feed throughout the world. The United Kingdom banned the use of penicillin and tetracycline for growth promotion in the 1970s. The United States banned the use of enrofloxacin in 2005. The European Union enforced a partial ban on antibiotics in 1999 and a complete ban was issued in 2006 [1]. The Council for Agricultural Science and Technology estimates that a ban on low level antibiotics in all livestock feed would result in collective losses of $\$ 1$ million to $\$ 28$ billion over a five year period. In addition, broiler producers could lose up to $\$ 12$ billion in the same amount of time if no substitutes are used in place of sub-therapeutic antibiotics [2, 3]. The ever changing nutritional concerns of society have spiked interest in the production and consumption of natural foods; phytogenic feed additives, along with organic acids and probiotics, may perhaps be viable alternatives to traditional antibiotic and growth promoter use and in 1984 companies took the first steps toward developing such products [4].

The prefix 'phyto' refers to plants hence; phytogenic feed additives (often called phytobiotics or botanicals) and are derived from certain plant parts such as: stems, leaves, roots, and/or flowers and contain a combination of essential oils, pungent substances, bitter substances, saponins, tannins, and flavanoids [5]. Phytogenic feed additives are primarily composed of essential oils which are concentrated, hydrophobic liquids containing highly volatile substances isolated by a physical process such as cold expression, steam distillation or fermentation, from an 
odoriferous plant of a single botanical species. The oil bears the name of the plant from which it is derived...Such oils were called essential because they were thought to represent the very essence of odor and flavor [6].

Phytogenic feed additives are purported to promote natural digestion while improving performance along with other various modes of action such as decreasing bacterial colony counts and fermentation products (ammonia and biogenic amines), reducing activity of the gut associated lymphatic system, increasing prececal nutrient digestion, and possessing antioxidative properties [7]. Essential oils possess strong aromatic properties which increase organo-leptic stimulation while bitter substances, stemming from herbs, are reported to regulate appetite and stimulate the secretion of gastric juices. Pungent substances such as paprika, garlic and onion are purported to function by increasing blood circulation leading to faster detoxification of the whole metabolism. All of these stimulate the secretion of digestive enzymes of mucosa and pancreas which increase nutrient digestibility [7].

Over the past decade, there has been a significant increase in scientific evidence surrounding the use of phytogenic feed additives and the potential for these additives to exhibit positive effects for animal production. However, it should be noted that the use of phytogenic feed additives is surrounded by conflicting research reports. While essential oils are said to increase organo-leptic or sensory stiumulation, there are few choice feeding studies available for conclusive evidence. Jugl-Chizzola et al. showed dose related depressions of palatability in pigs fed essential oils from fennel and caraway [8]. A feeding trial conducted by Muhl and Leibert found that swine fed diets containing an essential oil blend of thymol and carvacrol did not exhibit effects of improved digestion[11]. While on the contrary, there are reports of improved 
feed utilization involving swine fed diets containing phytogenic feed additives. Kroismayr et al. reported that performance variables were increased when piglets were fed a mix of essential oils stemming from oregano, anis, and citrus peels [12]. Increased feed intake is often seen in swine consuming feed supplemented with essential oils; however, this increase in feed intake may be a common result of other growth promoting feed additives such as organic acids, antibiotics and probiotics or a reflection of increased consumption capacity of swine and not directly related to the phytogenic feed additive per se [13]. Limited research exists surrounding the growth promoting effects of phytogenic feed additives in poultry however, Buchanan et al. reported that broilers fed diets containing plant extract blends (microencapsulated essential oils, bitter and pungent substances) had lower feed conversion ratios, improved live weight gain, and higher breast yield [3]. Windisch et al. completed an inclusive review regarding phytogenic feed additives and the proposed modes of actions of these products . The general conclusion encompassed in this review supports the idea that phytogenic feed additives may add to the set of non antibiotic growth promoters thereby increasing animal performance naturally [5].

\section{Advantages of Phytogenic Feed Additive Application:}

- Improved performance (Live weight gain and feed conversion ratio)

- Decreasing harmful bacteria in the gastrointestinal tract

- Increased feed intake (swine)

- Reduced mortality

- Increased egg production

- Improved barn climate (ammonia and biogenic amine reduction)

- Antioxidative actions 


\section{Antimicrobial Action and Improving Gut Function}

One of the main concerns involving poultry production, or any livestock production for human food, is the spread of disease from animal to man, better known as zoonotic diseases [14]. For this reason, there have been numerous studies involving phytogenic feed additives aiming at reducing harmful bacteria colonies in poultry. The antimicrobial effects are purported to arise from the hydrophobic essential oils ability to intrude into the bacterial cell membranes, disintegrate the structures which results in ion leakage [15]. Salmonella infections are asymptomatic in poultry flocks, but are associated with widespread human illness throughout the world. These infections can stem from raw or undercooked eggs as well as broiler meat. Salmonella is known to colonize in the gastrointestinal tract of poultry which has led to the development of measures to increase colonization resistance by manipulating the make-up of intestinal microbiota $[16,17]$. This is known as the competitive exclusion principle (CE), which states that "...two species competing for the same resources cannot stably coexist, if the ecological factors are constant. Either of the two competitors will always take over the other which leads to either the extinction of one of the competitors or its evolutionary or behavioral shift towards a different ecological niche" [17]. McElroy et al. found that both low and high levels of capsaicin, an essential oil from chili peppers, administered to birds 21, 28, and 42 days of age increased resistance to Salmonella without affecting weight gain, feed consumption, or carcass quality characteristics [18]. Lis-Balchin et al. studied the bioactivity of selected plant essential oils in vitro against Listeria monocytogenes. L. monocytogenes is present in soil, water, vegetables, and intestinal contents of a variety of birds, fish, insects and other animals. 
Human listeriosis is an erratic disease, which is associated with consumption of contaminated milk, soft cheese, under-cooked meat, unwashed raw vegetables, and cabbage [19].

93 essential oils were studied against 20 different strains of L. monocytogenes; white camphor, lemon verbena, angelica root, cassia, cinnamon leaf, clove leaf, basil, bergamot, pimento, bay, Eucalyptus radiata and citriodora, tea-tree and lemongrass were effective against all 20 strains [19].

Coccidiosis significantly affects the poultry industry in terms of economic loss which has been estimated at \$1-3 billion dollars annually [20]. Coccidiosis results from the species Eimeria which lives and multiplies in the intestinal tract resulting in tissue damage which can decrease digestion and nutrient absorption. The tissue damage resulting from coccidiosis may also increase the risk for exposure to other types of pathogens such as Clostridium or Salmonella [21].

Decreasing microbial activity is of high importance due to the effects associated with the disruption of enteric balance resulting from increased numbers of harmful bacteria. Bacterial by products are known to disturb $\mathrm{pH}$ balance in the GIT thereby reducing endogenous enzyme efficacy. The production of biogenic amines is also regarded as a serious problem mainly because their production results from the decarboxylation of essential amino acids. Therefore, the reduction of harmful bacterial colony counts may increase the supply of essential amino acids [22]. 


\section{Antioxidative Properties}

Many phytogenic compounds possess antioxidative properties which may help reduce oxidation of feed lipids similar to antioxidants that are currently employed in animal feeds ie; $\alpha$-tocopheryl acetate and BHT. Trials detailing information surrounding the application of traditional antioxidants versus the use of phytogenic feed additives as antioxidants are rapidly increasing $[23,24]$. During the past decade, phytogenic feed additive compounds have clearly demonstrated antioxidative effects in both meat and eggs [23,24,25,26] Essential oils (primarily from the Labiatae family) have been used in both human and companion animal food as natural antioxidants for quite some time [27] Govaris et al. detailed the effects of dietary application of antioxidants versus post mortem application to carcass meat and concluded that antioxidative effects are more pronounced when added to the diet [28]. Dietary additions of oregano essential oil improved tissue retention of $\alpha$-tocopheryl and a combination of oregano and rosemary oil further demonstrated these effects $[23,29]$

\begin{tabular}{|l|l|}
\hline $\begin{array}{c}\text { PFA Components and } \\
\text { Proposed Modes of Action }\end{array}$ & \\
\hline Component & Mode of Action \\
\hline Essential Oil & Increase digestive secretions \& N retention, appetizing \\
\hline Bitter Substances & Increase digestive secretions \& nutrient retention, appetizing \\
\hline Pungent Substances & Increase circulation \& metabolic processes, detoxification \\
\hline Saponins & $\begin{array}{l}\text { Enhance permeability of the gut wall, increase nutrient } \\
\text { adsorption, reduce ammonia }\end{array}$ \\
\hline Acid Complex & Acts against pathogenic bacteria, improved health status \\
\hline
\end{tabular}




\section{Exogenous Feed Enzymes}

The US animal feed industry currently faces tremendous hurdles due to increased ingredient cost and nutrient inconsistencies among source. Any solution to these problems must make sense economically and not comprise performance or health of the animal. Non-ruminant commercial diets typically consist of two or three ingredients that account for $>75 \%$ of the diet [30]. These ingredients per se contain various antinutritional factors (ANF); however, their increased cost has dictated the use of alternative ingredients containing sometimes greater quantities of ANF. It is under these conditions that exogenous enzyme supplementation that enables improved nutrient availability of feed ingredients containing ANF would be beneficial to both animal and producer. However, how nutritionists effectively employ exogenous feed enzymes in feed formulations is another hurdle entirely.

Phytase and non starch polysaccharide degrading enzymes are two exogenous feed enzymes that present problems for nutritionists that are attempting to obtain maximum enzyme value. The main purpose of phytase is to increase availability of plant phytate phosphorus but other minerals, carbohydrates and amino acids can be bound to phytic acid and made available due to phytate phosphorus digestion [31]. Non-starch polysaccharide degrading enzymes are used to increase digestibility of non-starch carbohydrates in the diet and reduce viscosity in the digesta that consequently improves overall nutrient digestibility [32]. Enzyme value is based on the quantities of specific nutrients expected to be spared by exogenous enzyme inclusion.

Simons et al. found when microbial phytase was added at a concentration of $1500 \mathrm{FYT} /$ $\mathrm{kg}$ feed to low-phosphorus broiler diets, the availability of $\mathrm{P}$ increased $60 \%$ while the $\mathrm{P}$ in excreta decreased 50\% [33]. Baker et al. showed an increase in both mineral digestibility and 
apparent metabolizable energy (AME) using various phytase concentrations. Ca digestibility increased when two phytase products (1 and 2) were added at concentrations of $500 \mathrm{FYT} / \mathrm{kg}$ and $250 \mathrm{FYT} / \mathrm{kg}$, respectively. AME increased in all treatments containing phytase [34]

Choct et al. found that diets containing low AME wheat supplemented with glycanase significantly increased the AME of the deficient wheat from $12.02 \mathrm{MJ} / \mathrm{kg}$ of dry matter to 14.94 $\mathrm{MJ} / \mathrm{kg}$ of dry matter. The low AME wheat + enzyme treatment also significantly decreased digesta viscosity [32]. Santos et al. showed that supplementation of xylanase in wheat based diets significantly decreased digestive viscosity therefore increasing nutrient digestibility in toms [35]. While research has proven the application of these enzymes can save significant dollars in the industry, nutritionists are still forced to gamble whether to utilize extra substrate nutrient matrix values fully. If the extra substrate nutrient values are not obtained after the matrix values are applied, the results could be very costly.

\section{Matrix Values}

Matrix values for various products are determined through extensive in-house analyses and implemented to estimate the nutrient sparing effects for metabolizable energy, amino acids, minerals, etc. For instance, proposed matrix values for a commercially available phytogenic feed additive are $14.6 \mathrm{kcal} / \mathrm{lb}$ for metabolizable energy, .03\% for lysine, $.02 \%$ for both methionine and threonine, and $.07 \%$ for calcium and available phosphorus. With these values, it would be possible for nutritionists to formulate nutritionally adequate diets while decreasing, by the respective amounts, the aforementioned nutrients. As ingredient cost continues to rise, correct application of feed additive matrix values is crucial in relieving high cost. Traditionally, 
exogenous enzymes have been employed to alleviate high diet costs. However, the potential may exist for simultaneous phytogenic feed additive and exogenous enzyme application into livestock feed to further decrease ingredient and overall diet cost.

\section{Determining TME $_{n}$ and TAAD Values}

Metabolizable energy (ME) is the measure of the energy available to the birds via the diet [36]. ME can be expressed as apparent (AME) or true (TME) metabolizable energy [37]. AME was the most common measure of ME in the past, however this measurement does not separate total excretory energy into independent estimates of fecal plus endogenous urinary energy [38]. In contrast, TME recognizes fecal and urinary energy (from non-dietary sources) as metabolized energy and is considered a more direct measure of energy availabilty [37,39]. AME values are derived from data obtained from test birds that are confined to metabolism cages in which experimental diets are fed ad libitum and total feed and excretory output are measured. This is known as the total collection method [40]. Bomb calorimetry is then employed to determine gross energy of both feed and exreta. Both AME and TME must be corrected to zero nitrogen balance so the values derived using birds with different nitrogen requirements (growing v. mature) will be comparable. $8.22 \mathrm{kcal}$ (amount of energy obtained when uric acid is completely oxidized) are added or subtracted from the ME value for each gram of nitrogen lost or gained to account for energy required in the excretion of urinary energy [37]. AME $E_{n}$ is derived from the following equation:

$A=$ total feed energy

$\mathrm{B}=$ total excreta energy 
$\mathrm{C}=$ total excreta energy of fasted roosters

$\mathrm{D}=\mathrm{N}$ correction factor $(8.22 \mathrm{kcal} / \mathrm{g})$.

$\mathrm{AME}_{\mathrm{n}}(\mathrm{kcal} / \mathrm{g})=(\mathrm{A}-\mathrm{B}-\mathrm{D}) /$ amount of feed $(\mathrm{g})$

Sibbald described the direct method for determining TME in 1976. Two groups of birds, control and experimental, are fasted for twenty-four hours, and the experimental birds are then precision fed a known quantity of feed (20-30g). The birds are then placed in raised wire cages and excreta are collected for 48 hours. Each bird may serve as its own negative control in which fecal and urinary energy estimates are derived [41]. Control birds are fasted for 24 hours and excreta is then collected for 48 hours. $\mathrm{TME}_{\mathrm{n}}$ is derived from the following equation:

$\mathrm{A}=$ total feed energy

$\mathrm{B}=$ total excreta energy

$\mathrm{C}=$ total excreta energy of fasted roosters

$\mathrm{D}=\mathrm{N}$ correction factor

$\mathrm{TME}_{\mathrm{n}}(\mathrm{kcal} / \mathrm{g})=(\mathrm{A}-\mathrm{B}+\mathrm{C}-\mathrm{D}) /$ amount of feed $(\mathrm{g})$

$\mathrm{TME}_{\mathrm{n}}$ values are more commonly utilized than those of $\mathrm{AME}_{\mathrm{n}}$. This is due to fundamental improvements upon the $\mathrm{AME}_{\mathrm{n}}$ method such as: providing nutrient values more similar to the actual biological value for poultry than previously achieved, decreased completion time, and easily reproducible methods [42]. 
Several modified methods exist for the determination of $\mathrm{TME}_{\mathrm{n}}$ and TAAD. TAAD values may be derived from methods similar to those that determine $\mathrm{TME}_{\mathrm{n}}$. The most commonly utilized method is that of McNab and Blair in which adult, male Single Comb White Leghorn roosters are cecectomized to determine energy and amino acid digestibilities of feed ingredients or complete diets [43]. The concentration of amino acids in the excreta is subtracted from the concentration of amino acids in the feedstuffs and related back to the amount of amino acid intake. Endogenous amino acid losses are determined through the use of starved birds or birds fed a protein free diet such as cornstarch [44].

The ceca comprise a major part of the large intestine in poultry and provide an environment suitable for numerous microorganisms [45]. The benefits of hindgut fermentation to poultry are unclear and past research has demonstrated that amino acids are not absorbed in the hindgut in significant quantities [46]. Researchers have stated that cecectomized birds should be used to prevent overestimation of amino acid digestibility in feedstuffs $[47,48]$

\section{Future Research}

Further justification of the proposed matrix values for this product may be pertinent in explaining the results of the following experiment. Future research will involve the justification of both $\mathrm{Ca}$ and AP matrix values of the same commercially available phytogenic feed additive (Appendix I).

Justification of these matrix values will be determined through live bird performance as well as bone mineralization assays similar to those described in Appendix II. 


\section{References}

1. Food Marketing Institute. 2006. Low level use of antibiotics in livestock and poultry. http://www.fmi.org/media/bg/antibiotics.pdf

2. Council for Agricultural Science and Technology. 1981. Antibiotics in animal feeds. Report No. 88. Counc. Agric. Sci. Technol., Ames, IA.

3. Buchanan, N.P., J. Hott., S. Cutlip., A. Rack., A. Asamer., J. Moritz., 2008. The Effects of a Natural Antibiotic Alternative and a Natural Growth Promoter Feed Additive on Broiler Performance and Carcass Quality. Journal of Applied Poultry Research. 2008. 17:202-210.

4. Ek Sze, DVM. Delacon Biotechnik. Phytogenic Feed Additive: A Natural Performer. http://www.livestockasia.com/conference_paper/slide/sze.pdf.

5. Windisch, W., K. Schedle., C. Plitzner., A. Kroismayr., 2008. Use of Phytogenic Products as Feed Additives for Swine and Poultry. Journal of Animal Science 2008. 86:140-148.

6. "essential oil." Encyclopedia Britannica. 2008. Encyclopedia Britannica Online. 01 Oct. 2008 <http://www.britannica.com/EBchecked/topic/193135/essential-oil>.

7. Delacon Phytogenic Feed Additives. 2004. Biostrong 505-The preventative solution for profitable poultry fattening. Delacon Biotechnik, Steyregg, Austria

8. Jugl-Chizzola, M., J. Spergser, F. Schilcher, J. Novak, A. Bucher, C. Gabler, W. Hagmuller, and K. Zitterl-Eglseer. 2005. Effects of Thymus vulgaris L. as feed additive in piglets and against haemolytic E. coli in vitro. Berl. Munch. Tierarztl. Wochenschr. 118:495-501.

9. Freitag, M., H. U. Hensche, H. Schulte-Sienbeck, and B. Reichelt. 1998. Biological effects of conventional and alternative performance enhancers.

10. "zoonotic disease." MedicineNet. 2004. 01 Oct. 2008. http://www.medterms.com/script/main/art.asp?articlekey $=20220$

11. Muhl, A., Leibert, F., 2007. No impact of a phytogenic feed additive on digestion and unspecific immune reaction in piglets. Journal of Animal Physiology and Animal Nutrition. 91:426-431.

12. Kroismayr, A., Schedle, K., Sehm, J., Pfaffl, MW., Plitzner, C., Foissy, H., Ettle, T., Mayer, H., Schreiner, M., Windisch, W. 2008. Effects of antimicrobial feed additives on gut microbiology and blood parameters of weaned piglets. Die Bodenkultur. 59:111-120.

13. Freitag, M., H. U. Hensche, H. Schulte-Sienbeck, and B. Reichelt. 1998. Biological effects of conventional and alternative performance enhancers.

14. "zoonotic disease." MedicineNet. 2004. 01 Oct. 2008.

15. Greathead, H., 2003. Plants and plant extracts for improving animal productivity. Proceedings of the Nutrition Society. 62:279-290.

16. Revelledo, L., A.J.P. Ferreira., G.C. Mead., 2006. Prospects in Salmonella

17. Control: Competitive Exclusion, Probiotics, and Enhancement of Avian Intestinal Immunity. Journal of Applied Poultry Research. 15: 341-351. 
18. McElroy, Audrey., Hot Pepper Oil May Prevent Salmonella in Poultry., Science Daily on the Web. 20 Aug. 2001., 15 Sept. 2008., http://www.sciencedaily.com/releases/2001/08/010820071840.htm.

19. Lis- Balchin, M., S.G. Deans., 1996. Bioactivity of selected plant essential oils against Listeria monocytogenes. Journal of Applied Microbiology. 82: 759-762.

20. Williams, R.B., 1999. A compartmentalized model for the estimation of the cost of coccidiosis to the world's chicken production industry. International Journal of Parasitology. 29:1209-1229

21. Helm, J.D. 1999. Coccidiosis in Poultry. Livestock Poultry Health Programs. <http://www.clemson.edu/public/lph/ahp/disease_links/images/coccidia.pdf.>.

22. Roth, F.X., Kirchgessner, M. 1998. Organic acids as feed additives for young pigs: nutritional and gastrointestinal effects. Journal of Animal and Feed Sciences. 8:25-33.

23. Botsoglou, N.A.,Christaki, E., Florou-Paneri, P., Giannenas, I., Papageorgiou, G., Spais, A.B., 2004. The effect of a mixture of herbal essential oils or alpha tocopheryl acetate on performance parameters and oxidation of body lipids in broilers. South African Journal of Animal Science. 34:52-61.

24. Botsoglou, N.A., Florou-Paneri, P., Botsolgou, E., Dotas, V., Giannenas, I., Koidas A., Mitrakos, P., 2005. The effect of feeding rosemary, oregano, saffron and alphatocopheryl acetate on hen performance and oxidative stability of eggs. South African Journal of Animal Science. 35:143-151.

25. Janz, J.A.M., Morel, P.C.H., Wilkinson, B.H.P., Purchas, R.W., 2007. Preliminary investigation of the effects of low-level dietary inclusion of fragrant essential oils and oleoresins on pig performance and pork quality. Meat Science 75: 350-355.

26. Young, J.F., Stagsted, J., Jensen, S.K., Karlsson A.H., Henckel, P., 2003. Ascorbic acid, alpha tocohperol, and oregano supplements reduce stress induced deterioration of chicken meat quality. Poultry Science. 82: 1343-1351.

27. Cuppett, S.L., Hall, S.A., 1998. Antioxidant property of Labiatae. Advances in Food and Nutrition Research. 42: 245-271.

28. Govaris, A., Botsoglou, N., Botsoglou, E., Ambrosiadis, I., 2004. Dietary versus post mortem use of oregano and/or alpha tocopheryl acetate in turkeys to inhibit development of lipid oxidation in meat during refrigerated storage. International Journal of Food Sciences and Nutrition. 55:115-123.

29. Basmacioglu, H., Tokusoglu, O., Ergul M., 2004. The effect of oregano and rosemary essential oils or alpha tocopheryl acetate on performance and lipid oxidation of meat enriched with n-3 PUFA's in broilers. South African Journal of Animal Science.34:197210.

30. Bedford, M.R., Schulze, H., 1999. Exogenous Enzymes for Pigs and Poultry. Nutrition Research Reviews 11:91-114.

31. Bedford, M.R., 2000. Exogenous enzymes in monogastric nutrition : their current value and future benefits. Animal Feed Science and Technology 86:1-13.

32. Choct, M., Hughes, R.J., Trimble, R.P., Angkanaporn, K., Annison, G. 1994. NonStarch Polysaccharide-Degrading Enzymes Increase the Performance of Broiler Chickens Fed Wheat of Low Apparent Metabolizable Energy. Journal of Nutrition 1235 (3):485492 
33. Simons, P.C.M, Versteegh H.A.J,Jongbloed A.W., Kemme P.A.,Slump P., K.D. Bos, Wolters M.G.E., Beudeker R.F. ,and Verschoor G.J., 1990. Improvement of phosphorus availability by microbial phytase in broiler and pigs. British. Journal of Nutrition. 64: 525-541.

34. Baker, N.J., Parsons A.S., and Moritz, J.S., 2007. Effects of Various Phytase Concentrations in Diets with Low-phytate Corn on Broiler Chick Performance and Nutrient Use. International Journal of Poultry Science 6 (2): 77-84.

35. A.A. Santos Jr, P.R. Ferket, J.L. Grimes and F.W. Edens. 2004. Dietary Supplementation of Endoxylanases and Phospholipase for Turkeys Fed Wheat-based Rations. International Journal of Poultry Science 3 (1): 20-32.

36. Vorha, P., 1966. Energy concepts for poultry nutrition. World's Poultry Science Journal. 22:6-24.

37. Harris, L.E., 1966. Biological energy interrelationships and glossary of energy terms. National Academic Science Publication. 1411.

38. Sibbald, I.R., 1976. A bioassay for true metabolizable energy in feedingstuffs. Poultry Science. 55: 303-308.

39. Owen, R.B., Jr., Reinecke, J., 1979. Bioenergetics of breeding dabbling ducks. 71-93.

40. Vohra, P., 1972. Evaluation of metabolizable energy for poultry. World's Poultry Science Journal. 29:204-214.

41. Sibbald, I.R., Price, K., 1980. Variability in metabolic plus endogenous energy losses of adult cockerels and in the true metabolizable energy values and rates of passage of dehydrated alfalfa. Poultry Science. 59:1275-1279.

42. Dudley-Cash,W.A., 2009. A landmark contribution to poultry science- A bioassay for true metabolizable energy in feedingstuffs. Poultry Science. 88:832-834.

43. McNab, J.M., Blair, J.C., 1988. Modified assay for true and apparent metabolizable energy based on tube feeding. British Poultry Science. 29:697-707.

44. Sibbald, I.R., 1987. Estimation of bioavailable amino acids in feedingstuffs for poultry and pigs: a review with emphasis on balance experiments. Can. J. of An. Sci., 67:221-330.

45. Barnes, E.M., Mead, G.C., Barnum, D.A., Harry, E.G., 1972. The intestinal flora of the chicken in the period of 2 to 6 weeks of age, with particular reference to anaerobic bacteria. British Poultry Science. 13:311-326.

46. Webb, K.E., 1990. Intestinal absorption of protein hydrolysis products: A review. Journal of Animal Science. 68:3011-3022.

47. Johnson, R.J., 1992. Principles, problems, and application of amino acid digestibility in poultry. World's Poultry Science Journal. 48: 232-246.

48. Ragland, D., Thomas, C.R., Elkin, R.G., Shafer, D.J., and Adeola, O., 1999. The influence of cecectomy on metabolizable energy and amino acid digestibility of select feedstuffs for White Pekin ducks. Poultry Science. 78:707-713. 


\title{
Justifying Phytogenic Feed Additive Matrix Values in Conjunction with Exogenous Feed Enzymes
}

\author{
L. K. Shires*,S.A. Loop, C.K. Gehring, K.R. Beaman and J. S. Moritz \\ *Division of Animal and Nutritional Sciences, West Virginia University, \\ Morgantown, WV 26506
}

\section{SUMMARY}

Phytogenic feed additives are purported to possess antimicrobial properties as well as nutrient sparing characteristics that may aid in alleviating high diet costs; however, in order for PFA's to assist nutritionists in decreasing diet cost, matrix values must be determined and implemented in feed formulation. Study 1 evaluated proposed matrix values for a commercially available PFA and assessed nutrient sparing when the product was combined with commercial phytase, carbohydrase and protease. The most remarkable proposed matrix values were 32.2 $\mathrm{kcal} / \mathrm{kg}$ for metabolizable energy and $0.07 \%$ for both Ca and AP. The objective of Study 2 was to determine true amino acid digestibility (TAAD) and nitrogen corrected true metabolizable energy $\left(\mathbf{T M E}_{\mathbf{n}}\right)$. Dietary treatments for both studies included a basal, basal with phytogenic product matrix value, basal with phytogenic product matrix value and phytogenic product, and similar treatments evaluating the phytogenic product matrix with exogenous enzyme products. Decreasing the basal diet by the proposed phytogenic matrix values decreased broiler live weight gain and increased feed conversion ratio $(\mathrm{P} \leq 0.05)$. However, when the same diet included the phytogenic feed additive, live weight gain and feed conversion ratio were restored to that of the basal diet $(\mathrm{P}>0.05)$. The proposed matrix values of the specific PFA tested were justified. However, the PFA was not additive or synergistic with exogenous enzymes. Nitrogen corrected 
true metabolizable energy and TAAD data did not differ when the diets varied based on the PFA per se $(\mathrm{P}>0.05)$. However, when the PFA was incorporated using proposed matrix values and used in conjunction with exogenous enzymes and their matrix values, $\mathrm{TME}_{\mathrm{n}}$ and several tested TAAD values were decreased $(\mathrm{P} \leq 0.05)$. Mechanistic speculation for decreased nutrient digestibility may perhaps involve reductions in gut microflora due to the PFA as well as simultaneous reduction in substrate concentrations.

Key words: phytogenic additives, matrix values, exogenous enzymes, true amino acid digestibility

\section{DESCRIPTION OF PROBLEM}

Consumers have increasingly expressed concern about the development of antibiotic resistant bacteria resulting from continual, low level incorporation of antibiotics in livestock feed. This has prompted the ban of numerous antibiotics in animal feed throughout the world. Phytogenic feed additives along with organic acids and probiotics, represent alternatives to traditional antibiotic use and in 1984 companies took the first steps toward developing such products [1]. The prefix 'phyto' refers to plants; hence, phytogenic feed additives (often called phytobiotics or botanicals) are derived from certain plant parts such as: stems, leaves, roots, and/or flowers and contain a combination of essential oils, pungent substances, bitter substances, saponins, tannins, and flavanoids [2]. Phytogenic feed additives typically contain a high percentage of essential oils which are concentrated, hydrophobic liquids containing highly volatile substances isolated by a physical process such as cold expression, steam distillation or fermentation, from an odoriferous plant of a single botanical species. The oil bears the name of 
the plant from which it was derived. Such oils were called essential because they were thought to represent the very essence of odor and flavor [3]. Phytogenic feed additives are marketed as promoting natural digestion and improving performance associated with modes of action such as decreasing harmful bacterial colony counts and fermentation products (ammonia and biogenic amines), reducing activity of the gut associated lymphatic system, increasing prececal nutrient digestion, and having antioxidative actions [4]. Essential oils possess strong aromatic properties which increase organoleptic stimulation while bitter substances, stemming from herbs, are reported to regulate appetite and stimulate the secretion of gastric juices. Pungent substances such as paprika, garlic and onion are purported to function by increasing blood circulation, leading to faster detoxification of the metabolism. All of these stimulate the secretion of digestive enzymes of mucosa and pancreas which increase nutrient digestibility [5]. Perhaps when these products are used alongside conventional exogenous feed enzymes, feed digestion, and consequent animal performance could be further enhanced. The objective of Study 1 was to evaluate the proposed matrix values for a commercially available PFA and to assess nutrient sparing when the product was combined with a commercial phytase, carbohydrase, and protease. Assessment was based on growth performance of broiler chickens. The objective of Study 2 was to evaluate the proposed matrix values for a commercially available PFA through TAAD and $\mathrm{TME}_{\mathrm{n}}$ measures using cecectomized Single Comb White Leghorn rooster models.

\section{MATERIALS AND METHODS}

Feed Manufacture. Eight dietary treatments, formulated to meet Cobb-Vantress Inc. [6] least cost starter recommendations, were manufactured at West Virginia University's Pilot feedmill 
(Table 1). Each of the eight dietary treatments totaled $363 \mathrm{~kg}$ and were subsequently divided into four $91 \mathrm{~kg}$ batches. The decreased batch size was created in order to increase mixer uniformity based on WVU feed mill capabilities. Each batch was mixed in a horizontal ribbon mixer for twenty minutes[7].

Study 1. A total of 1,412 male Cobb 500 broilers were obtained from a commercial hatchery at hatch and 1,344 of these broilers were selected based on weight to create uniformity in initial pen weight. Weighing occurred on day four and groups of selected birds were randomly allotted to 1 of 64 floor pens $[0.69 \times 2.44 \mathrm{~m}(2.26 \times 8.00 \mathrm{ft})]$ located in 2 rooms joined by a woven wire barrier that allowed heat and ventilation to move freely between the rooms. Rooms were located in a cross-ventilated negative-pressure house with forced-air brooders. Each room was considered one block, and each block was composed of a group of 32 pens. Broilers were placed at a stocking density of 21 birds/pen $\left[0.065 \mathrm{~m}^{2} / \mathrm{bird}\left(0.70 \mathrm{ft}^{2} /\right.\right.$ bird $\left.)\right]$ and were provided with feed and water, supplied through Kuhl feed pans adapted to hoppers and Ziggity nipple drinkers, for ad libitum consumption[8,9]. During the 1-3 d pretest period, broiler chicks were fed a nutrient deficient diet that utilized the PFA matrix without the PFA. This was done so birds would not be on a high plane of nutrition that could confound treatment effects. On day four, each of the eight experimental diets were randomly assigned to pens within each block. The matrix values established for this particular PFA were $32.2 \mathrm{kcal} / \mathrm{kg}$ (14.6 kcal/lb) for metabolizable energy, $0.03 \%$ for Threonine, $0.02 \%$ for both Methionine and Lysine, and $0.07 \%$ for both AP and calcium [4]. The matrix values for the carbohydrase-protease blend were $75.8 \mathrm{kcal} / \mathrm{kg}(34.4$ $\mathrm{kcal} / \mathrm{lb}$ ) for metabolizable energy and $0.5 \%$ for crude protein [10]. The phytase that was 
implemented had calculated matrix values of $0.1 \%$ for available phosphorus [11]. Temperature of the rooms was initially maintained at $32.2^{\circ} \mathrm{C}\left(90.0^{\circ} \mathrm{F}\right)$ and incrementally decreased to $23.9^{\circ} \mathrm{C}$ $\left(75.0^{\circ} \mathrm{F}\right)$ during the experimental period of 4 to 21 days. Live weight gain (LWG), feed intake (FI), and feed conversion ratio (FCR) were determined from 4-21 days. Feed conversion ratio calculations included mortality weight. All animals were reared according to protocols established by the West Virginia University Animal Care and Use Committee [ACUC \# 080894].

Study 2. A total of 32 cecectomized SCWL roosters, approximately 50 weeks of age, were used to estimate TAAD as well as $\mathrm{TME}_{\mathrm{n}}$ for the eight treatments used in the previous study using a modified procedure of Sibbald [12]. On day one of the experiment, roosters were placed on a three week pre-test utilizing the specific diet to be precision fed. Feed and water were supplied ad libitum during this phase. Upon completion of the pre-test, roosters were placed in environmentally controlled rooms containing raised wire cages. The room consisted of four blocks based on location, and each block was composed of eight cages. Diets were randomly assigned to caged birds within each block. Feed was withheld for 24 hours to ensure proper emptying of the gastrointestinal tract; birds were then precision fed 30 grams of feed from one of the eight dietary treatments corresponding to the pre-test diets. Total excreta were collected over a 48 hour period. Upon completion, roosters were placed back on their respective pre-test diets for three weeks in order to provide adequate rest and recovery. Rooster models were then used in a second series of this study to obtain eight replications for each dietary treatment. Each bird was precision fed cornstarch for amino acid quantification and feed was withdrawn for 24 
hours and excreta collected for 48 hours in order to quantify endogenous energy losses. After the experiment, each bird was used as its own control, similar to Latshaw and Freeland [13]. , Collected excreta were lyophilized, weighed, and ground. Feed and excreta samples were submitted to commercial laboratories to quantify amino acids, gross energy, and nitrogen $[14],[15],[16],[17]$.

\section{Statistical Analysis}

Analyses were completed using GLM ANOVA procedure from the SAS Institute [18] and when significant differences were detected, treatment means were separated and compared using Fisher's LSD. Means were considered significantly different at $(\mathrm{P} \leq 0.05)$. Pre-planned orthogonal contrasts of treatments three vs. four and treatments seven vs. eight were employed to determine the effects of the PFA on metabolism of reduced nutrient diets. Although our omnibus F-test was non significant, several of our contrasts demonstrated significant treatment differences (Table. 3). This situation has been detailed by Milliken and Johnson [19].

\section{RESULTS and DISCUSSION}

Study 1. Performance data for the four to twenty-one day period are illustrated in Table 2. The basal diet top dressed with the PFA (Treatment 2) demonstrated similar LWG values and increased FCR values when compared to the basal diet (Treatment 1$)(\mathrm{P}>0.05)$ possibly resulting from the increase in FI due to the PFA. When the PFA matrix values were applied to dietary treatments lacking the PFA (Treatment 3), broiler LWG was decreased and feed conversion ratio was increased compared to broilers fed the basal diet (Treatment 1) $(\mathrm{P} \leq 0.05)$. However, when 
the PFA matrix was applied and the PFA was included (Treatment 4), LWG and FCR were restored to values comparable to that of the basal diet (Treatment 1) $(\mathrm{P}>0.05)$. The dietary treatment with enzyme matrices applied with enzymes (Treatment 5) demonstrated LWG and FCR values similar to that of the basal diet (Treatment 1) $(\mathrm{P}>0.05)$ demonstrating the efficacy of the exogenous enzymes used. The application of all matrices (exogenous enzyme matrices and PFA matrices) without the inclusion of PFA but with enzymes (Treatment 7), proved detrimental to both LWG and FCR as compared to the basal treatment (Treatment 1) $(\mathrm{P}<0.05)$. The inclusion of the PFA to this treatment (Treatment 8) could not restore LWG and FCR values. In fact, the combination of all products and their respective matrices proved sub-additive. This result could possibly be explained by full utilization of the PFA and enzyme matrix values resulting in a plane of nutrition too low to be overcome. Competition for similar substrates between the PFA, exogenous, and endogenous enzymes may also explain this phenomenon [20]. Potential increases in endogenous enzyme secretions due to the PFA may have been ineffective due to substrates being digested by exogenous enzymes resulting in an energy expensive metabolic state. In 2005, the European Food Safety Authority (EFSA) presented the opinion of the FEEDAP Scientific Panel on the safety and efficacy of a specific feed additive. It was concluded that negative interactions between feed additives and exogenous enzymes should not be dismissed [21].

Study 2. Energy and amino acid digestibility data from cecectomized SCWL roosters are illustrated in Table 3. No significant difference among $\mathrm{TME}_{\mathrm{n}}$ or TAAD were demonstrated according to the omnibus F-test. However, pre-planned orthogonal contrasts were implemented 
for treatment three vs. four and treatment seven vs. eight. A numerical increase in $\mathrm{TME}_{\mathrm{n}}$ values were observed due to the incorporation of the PFA when comparing treatment two vs. one, four vs. three, and six vs. five $(\mathrm{P}>0.05)$. However, $\mathrm{TME}_{\mathrm{n}}$ values had a tendency to decrease when all products matrices were applied, exogenous enzymes included, and the PFA included compared to the PFA being excluded (Treatment 7 vs. Treatment 8$)(\mathrm{P}<0.06)$. When comparing TAAD of treatments eight vs. seven, Aspartic acid, Glutamic acid, Valine, and Leucine, demonstrated trends toward decreased digestibility $(\mathrm{P}=0.0798),(\mathrm{P}=0.0645),(\mathrm{P}=0.0510),(\mathrm{P}=0.0792)$, respectively ; while Proline, Alanine, Methionine, and Isoleucine showed decreased digestibility $(P=0.0117),(P=0.0340),(P=0.0230),(P=0.0400)$, respectively. Similar speculations as described in Study 1 results may also be relevant in explaining this data. There was no significant improvement in amino acid digestibility when comparing treatments three vs. four (P>0.05); however, proposed PFA matrix values for amino acids were relatively low to begin with.

\section{CONCLUSIONS and APPLICATIONS}

1. The PFA matrix values were justified when the product was used alone in the 4-21 d broiler performance study.

2. The PFA and exogenous enzymes with all matrices applied were sub-additive, increasing FCR and decreasing LWG in the 4-21 d broiler performance study and decreasing $\mathrm{TME}_{\mathrm{n}}$ and several tested TAAD in the precision fed rooster study. 


\section{References and Notes}

1. Ek Sze, DVM. Delacon Biotechnik. 2006.Phytogenic Feed Additive: A Natural Performer. 01. Oct. 2008 <http://www.livestockasia.com/conference_paper/slide/sze.pdf $>$.

2. Windisch, W., K. Schedle., C. Plitzner., A. Kroismayr., 2008. Use of Phytogenic Products as Feed Additives for Swine and Poultry. Journal of Animal Science 2008. 86:140-148.

3. Lee,KW, H. Everts , H. Kappert,M. Frehner, R. Losa ,A. Beynen.,2008. Effects of dietary essential oil components on growth performance, digestive enzymes and lipid metabolism in female broiler chickens. British Poultry Science Jul. 44(3): 450-7. 2003.

4. Delacon Phytogenic Feed Additives. 2004. Biostrong 510 - The performizer for improved nutrient retention. Delacon Biotechnik, Steyregg, Austria.

5. Buchanan, N.P., J. Hott., S. Cutlip., A. Rack., A. Asamer., J. Moritz., 2008. The Effects of a Natural Antibiotic Alternative and a Natural Growth Promoter Feed Additive on Broiler Performance and Carcass Quality. Journal of Applied Poultry Research. 2008. 17:202-210.

6. Cobb-Vantress Inc., Siloam Springs, AR.

7. Davis Precision Mixer, Model S-1; H.C. Sons Manufacturing Co., Inc., Bonner Springs, KS.

8. Feed pan and hopper; Kuhl Corporation, Flemington, NJ.

9. Water system; Ziggity Systems Inc., Middlebury, IN.

10. Avizyme 1502; Danisco A/S, Cedar Rapids, IA

11. OptiPhos 2000; OptiPhos, Sheridan, IN

12. Sibbald, I. R. 1976. A bioassay for true metabolizable energy in feedingstuffs. Poult. Sci. 55:303-308. (Feed was withheld for 24 hours, approximately 30 grams of feed were precision fed, and excreta was collected for 48 hours.)

13. Latshaw, J.D., K. Freeland., 2009. Metabolizable Energy Values Determined with Intact and Cecectomized Roosters. Poult. Sci. 2008. 87:101-103.

14. CEPS, Central Analytical Laboratory, University of Arkansas, Fayetteville, AR

15. Experiment Station Chemical Laboratories, Agricultural Experiment Station, Univ. Missouri, Columbia, MO

16. Isoperibol oxygen bomb calorimeter model 1266, Parr Instrument Co., Moline, IL.

17. Kjeltec Auto 1030 analyzer, Foss Tecator, Eden Praire, MN.

18. SAS Institute. 2000. The SAS System for Windows 2000. Release 8.1. SAS Inst. Inc., Cary, NC.

19. Milliken, G. A., and D.E.,Johnson. (1992) Analysis of Messy Data: Designed Experiments. Van Nostrand Reinhold, New York. 
20. Olokusi, O.A., A.J., Cowieson, O. Adeola., 2009. Age-Related Influence of a Cocktail of Xylanase, Amylase, and Protease or Phytase Individually or in Combination in Broilers. Poult Sci 2007. 86:77-86.

21. Anadon, A., M. Abroix Arzo, G. Bories, P. Brantom, J. Brufau de Barbera, A. Chesson, P. S. Concconcelli, J. de Knecht, N. Dierick, G. Flachowsky, A. Franklin, J. Gropp, A. K. Haldorsen, I. Halle, A. Mantovani, K. Peltonen, G. Rychen, P. Sanders, A. Soares, P. Wester, and W. Windisch. 2005. Opinion of the FEEDAP Panel on the safety and efficacy of the product Farmatan for rabbits and piglets. The EFSA Journal 222:1-20. 
Table 1. Diet Formulations for Treatments 1-8 (Study 1 and 2)

\begin{tabular}{|c|c|c|c|c|c|c|c|c|}
\hline \multicolumn{9}{|l|}{ Treatment $^{1}$} \\
\hline Ingredient & 1 & 2 & 3 & 4 & 5 & 6 & 7 & 8 \\
\hline Corn & 56.70 & 56.70 & 56.49 & 56.49 & 55.1 & 55.1 & 54.8 & 54.8 \\
\hline Soybean meal (48\%) & 24.54 & 24.54 & 23.51 & 23.51 & 23.63 & 23.63 & 22.73 & 22.73 \\
\hline Cellulose $^{2}$ & 1.91 & 1.91 & 3.40 & 3.40 & 4.46 & 4.46 & 5.85 & 5.85 \\
\hline Wheat middlings & 5.00 & 5.00 & 5.00 & 5.00 & 5.00 & 5.00 & 5.00 & 5.00 \\
\hline $\mathrm{DDGS}^{3}$ & 5.00 & 5.00 & 5.00 & 5.00 & 5.00 & 5.00 & 5.00 & 5.00 \\
\hline Soybean oil & 3.00 & 3.00 & 3.00 & 3.00 & 3.00 & 3.00 & 3.00 & 3.00 \\
\hline Tricalcium phosphate & 1.50 & 1.50 & 1.14 & 1.14 & .96 & .96 & 0.60 & 0.60 \\
\hline Limestone & 0.66 & 0.66 & 0.74 & 0.74 & 1.05 & 1.05 & 1.14 & 1.14 \\
\hline Porcine $\mathrm{MBM}^{4}$ & 0.51 & 0.51 & 0.51 & 0.51 & 0.51 & 0.51 & 0.51 & 0.51 \\
\hline DL - methionine & 0.29 & 0.29 & 0.29 & 0.29 & 0.30 & 0.30 & 0.29 & 0.29 \\
\hline NB $3000^{5}$ & 0.25 & 0.25 & 0.25 & 0.25 & 0.25 & 0.25 & 0.25 & 0.25 \\
\hline Lysine & 0.33 & 0.33 & 0.33 & 0.33 & 0.35 & 0.35 & 0.35 & 0.35 \\
\hline Salt & 0.15 & 0.15 & 0.20 & 0.20 & 0.22 & 0.22 & 0.26 & 0.26 \\
\hline Threonine & 0.14 & 0.14 & 0.14 & 0.14 & 0.15 & 0.15 & 0.14 & 0.14 \\
\hline PFA or sand & 0.015 & 0.015 & 0.015 & 0.015 & 0.015 & 0.015 & 0.015 & 0.015 \\
\hline Avizyme $1502^{6}$ & -- & -- & -- & -- & 0.05 & 0.05 & 0.05 & 0.05 \\
\hline Optiphos $2000^{7}$ & -- & -- & -- & -- & 0.0125 & 0.0125 & 0.0125 & 0.0125 \\
\hline $\mathrm{ME}(\mathrm{kcal} / \mathrm{kg})$ & 3066.63 & 3066.63 & 3034.44 & 3034.44 & 2990.79 & 2990.79 & 2958.60 & 2958.60 \\
\hline $\mathrm{CP}(\%)$ & 19.55 & 19.55 & 19.03 & 19.03 & 19.00 & 19.00 & 18.53 & 18.53 \\
\hline Lysine (\%) & 1.19 & 1.19 & 1.16 & 1.16 & 1.18 & 1.18 & 1.15 & 1.15 \\
\hline Met+Cys (\%) & 0.88 & 0.88 & 0.86 & 0.86 & 0.87 & 0.87 & 0.85 & 0.85 \\
\hline Threonine (\%) & 0.76 & 0.76 & 0.74 & 0.74 & 0.75 & 0.75 & 0.73 & 0.73 \\
\hline Tryptophan (\%) & 0.24 & 0.24 & 0.23 & 0.23 & 0.23 & 0.23 & 0.23 & 0.23 \\
\hline Arginine $(\%)$ & 1.24 & 1.24 & 1.20 & 1.20 & 1.20 & 1.20 & 1.16 & 1.16 \\
\hline Isoleucine $(\%)$ & 0.84 & 0.84 & 0.82 & 0.82 & 0.81 & 0.81 & 0.79 & 0.79 \\
\hline Calcium (\%) & 0.84 & 0.84 & 0.77 & 0.77 & 0.84 & 0.84 & 0.77 & 0.77 \\
\hline Available P (\%) & 0.42 & 0.42 & 0.35 & 0.35 & 0.32 & 0.32 & 0.25 & 0.25 \\
\hline Sodium (\%) & 0.18 & 0.18 & 0.18 & 0.18 & 0.18 & 0.18 & 0.18 & 0.18 \\
\hline
\end{tabular}

Treatments: 5=Basal+enzymes, enzyme matrices, no PFA

6=Basal+enzymes, enzyme matrics, PFA

2=Basal + PFA 7=Basal+enzymes, enzyme matrices, PFA matrix, no PFA

4=Basal+PFA \& PFA matrix $\quad 8=$ Basal+enzymes, enzyme matrices, PFA matrix, and PFA

${ }^{2}$ Solka-Floc; International Fiber Corporation, North Tonawanda, NY. 
${ }^{3}$ Dried distillers grains with corn solubles

${ }^{4}$ Porcine meat and bone meal (55\%)

${ }^{5}$ Supplied (per kg of diet): manganese, $0.02 \%$; zinc, $0.02 \%$; iron, $0.01 \%$; copper, $0.0025 \%$; iodine, $0.0003 \%$; selenium,

$0.00003 \%$; folic acid, $0.69 \mathrm{mg}$; choline, $386 \mathrm{mg}$; riboflavin, $6.61 \mathrm{mg}$; biotin, $0.03 \mathrm{mg}$; vitamin B6, $1.38 \mathrm{mg}$; niacin, 27.56

$\mathrm{mg}$; pantothenic acid, $6.61 \mathrm{mg}$; thiamine, $2.20 \mathrm{mg}$; vitamin B12, $0.01 \mathrm{mg}$; vitamin E, $16.53 \mathrm{IU}$; vitamin D3, 2,133 ICU;

vitamin A, 7,716 IU.

${ }^{6}$ Danisco USA Inc. Cedar Rapids, Iowa

${ }^{7}$ OptiPhos. Sheridan, IN 
Table 2. Performance data for 4-21-d broiler chickens (Study 1)

\begin{tabular}{|l|l|l|l|l|}
\hline Treatment $^{1}$ & $\begin{array}{l}\text { Pen Feed Intake } \\
(\mathrm{kg})\end{array}$ & $\begin{array}{l}\text { Live Weight } \\
\text { Gain }(\mathrm{kg} / \mathrm{bird})\end{array}$ & Feed Conversion Ratio (kg/kg) & Mortality \\
\hline 1 & 20.66 & $.60^{\mathrm{a}}$ & $1.66^{\mathrm{c}}$ & 1.79 \\
\hline 2 & 21.47 & $.60^{\mathrm{ab}}$ & $1.73^{\mathrm{ab}}$ & 1.19 \\
\hline 3 & 20.61 & $.58^{\mathrm{c}}$ & $1.72^{\mathrm{b}}$ & 1.79 \\
\hline 4 & 20.98 & $.60^{\mathrm{ab}}$ & $1.68^{\mathrm{bc}}$ & 0.60 \\
\hline 5 & 20.93 & $.59^{\mathrm{abc}}$ & $1.69^{\mathrm{bc}}$ & 0.00 \\
\hline 6 & 20.86 & $.59^{\mathrm{bc}}$ & $1.71^{\mathrm{bc}}$ & 1.19 \\
\hline 7 & 20.81 & $.56^{\mathrm{d}}$ & $1.78^{\mathrm{a}}$ & 0.60 \\
\hline 8 & 20.63 & $.55^{\mathrm{d}}$ & $1.78^{\mathrm{a}}$ & 0.00 \\
\hline $\begin{array}{l}\text { ANOVA } \\
\text { values }\end{array}$ & 0.0621 & $<0.0001$ & 0.0002 & - \\
\hline LSD ${ }^{2}$ & - & 0.013 & 0.054 & 0.4067 \\
\hline
\end{tabular}

${ }^{\mathrm{a}-\mathrm{d}}$ Means within a column without a common superscript differ $(\mathrm{P} \leq .05)$.

${ }^{1}$ Treatments:

$1=$ Basal

$2=$ Basal + PFA

$3=$ Basal+PFA matrix, no PFA

5=Basal+enzymes, enzyme matrices, no PFA

$6=$ Basal+enzymes, enzyme matrics, PFA

4=Basal+PFA \& PFA matrix

$7=$ Basal+enzymes, enzyme matrices, PFA matrix, no PFA

${ }^{2}$ Fisher's LSD value

$8=$ Basal+enzymes, enzyme matrices, PFA matrix, and PFA 
Table 3. Cecectomized Rooster $\mathrm{TME}_{\mathrm{n}}{ }^{1}$ and $\mathrm{TAAD}^{2}$ Values (Study 2)

\begin{tabular}{|c|c|c|c|c|c|c|c|c|c|c|c|c|}
\hline Treatment $^{3}$ & $\mathrm{TME}_{\mathrm{n}} \pm \mathrm{SD}$ & AATD \pm SD & TTD \pm SD & GATD \pm SD & PTD \pm SD & ALTD \pm SD & CYTD $\pm S D$ & VATD \pm SD & METD \pm SD & ILTD \pm SD & LETD $\pm S D$ & LYTD \pm SD \\
\hline 1 & $3128.05 \pm 105.86$ & $88.15 \pm 4.26$ & $83.19 \pm 4.05$ & $92.29 \pm 3.50$ & $88.72 \pm 4.05$ & $84.29 \pm 6.09$ & $76.20 \pm 15.09$ & $87.36 \pm 6.03$ & $92.45 \pm 5.40$ & $88.05 \pm 5.73$ & $90.58 \pm 4.10$ & $90.62 \pm 3.70$ \\
\hline 2 & $3223.05 \pm 183.16$ & $89.09 \pm 7.89$ & $85.73 \pm 14.32$ & $92.25 \pm 6.53$ & $90.54 \pm 9.68$ & $85.26 \pm 10.83$ & $82.85 \pm 19.82$ & $89.33 \pm 9.89$ & $93.46+5.98$ & $89.68 \pm 8.88$ & $92.06 \pm 7.16$ & $90.97 \pm 7.04$ \\
\hline 3 & $3022.96 \pm 265.38$ & $87.93 \pm 5.65$ & $85.86 \pm 7.83$ & $92.43 \pm 3.55$ & $90.77 \pm 4.55$ & $84.68 \pm 5.99$ & $81.13 \pm 15.53$ & $89.72 \pm 5.84$ & $94.99 \pm 3.13$ & $89.36 \pm 5.53$ & $91.80 \pm 4.51$ & $90.70 \pm 4.15$ \\
\hline 4 & $3119.01 \pm 204.31$ & $88.83 \pm 4.62$ & $85.93 \pm 6.04$ & $92.25 \pm 4.33$ & $90.04 \pm 4.49$ & $86.91 \pm 4.43$ & $82.75 \pm 11.73$ & $89.14 \pm 5.75$ & $94.80 \pm 3.78$ & $89.84 \pm 4.84$ & $91.38 \pm 4.28$ & $90.47 \pm 3.66$ \\
\hline 5 & $3101.79 \pm 218.84$ & $86.58 \pm 6.38$ & $83.76 \pm 9.43$ & $90.78 \pm 5.23$ & $86.69 \pm 8.31$ & $80.24 \pm 10.31$ & $78.25 \pm 18.36$ & $85.53 \pm 8.40$ & $92.93 \pm 4.29$ & $86.62 \pm 7.35$ & $89.55 \pm 6.07$ & $88.12 \pm 6.53$ \\
\hline 6 & $3171.62 \pm 339.81$ & $89.15 \pm 2.84$ & $86.79 \pm 3.76$ & $92.53 \pm 1.55$ & $89.14 \pm 2.38$ & $83.98+3.91$ & $76.59 \pm 9.45$ & $88.61 \pm 2.84$ & $94.22 \pm 2.15$ & $89.53 \pm 2.80$ & $91.88 \pm 1.99$ & $87.99 \pm 6.01$ \\
\hline 7 & $3179.82 \pm 267.87$ & $88.74 \pm 5.86$ & $82.45 \pm 7.71$ & $92.40 \pm 5.77$ & $88.13 \pm 8.17$ & $86.35 \pm 9.02$ & $74.80 \pm 21.39$ & $87.76 \pm 8.44$ & $95.15 \pm 3.40$ & $89.54 \pm 6.54$ & $91.20 \pm 5.76$ & $88.95 \pm 814$ \\
\hline 8 & $2954.66 \pm 213.35$ & $83.63 \pm 4.38$ & $79.05 \pm 7.09$ & $87.89 \pm 3.88$ & $85.51 \pm 5.00$ & $78.15 \pm 6.63$ & $65.76 \pm 21.61$ & $81.61 \pm 5.72$ & $90.41 \pm 3.72$ & $83.19 \pm 5.03$ & $86.81 \pm 3.76$ & $85.53 \pm 7.87$ \\
\hline $\begin{array}{l}\text { ANOVA } \\
\text { P - Value }\end{array}$ & 0.3598 & 0.4812 & 0.6063 & 0.4457 & 0.6822 & 0.2781 & 0.5691 & 0.3140 & 0.2981 & 0.3374 & 0.4333 & 0.6540 \\
\hline TRT 3 v. 4 & 0.4113 & 0.7403 & 0.9870 & 0.9358 & 0.8174 & 0.5557 & 0.8512 & 0.8670 & 0.9264 & 0.8739 & 0.8636 & 0.9420 \\
\hline TRT 7 v. 8 & 0.0575 & 0.0645 & 0.4060 & 0.05102 & 0.4082 & 0.0340 & 0.2968 & 0.0798 & 0.0230 & 0.0400 & 0.0792 & 0.2745 \\
\hline
\end{tabular}

${ }^{1}$ True Metabolizable Energy corrected for Nitrogen

${ }^{2} \mathrm{AATD}=$ Aspartic acid true digestibility; TTD=Threonine true digestibility; GATD=Glutamic acid true digestibility; PTD=Proline true digestibility; ALTD=Alanine true digestibility; CYTD= Cysteine true digestibility; VATD= Valine true digestibility; METD= Methionine true digestibility; ILTD= Isoleucine true digestibility; LETD= Leucine true digestibility; LYTD= Lysine true digestibility

${ }^{3}$ Treatments:

$1=$ Basal

$2=$ Basal + PFA

5=Basal+enzymes, enzyme matrices, no PFA

2=Basal + PFA

4=Basal+PFA \& PFA matrix

6=Basal+enzymes, enzyme matrics, PFA

7=Basal+enzymes, enzyme matrices, PFA matrix, no PFA

$8=$ Basal+enzymes, enzyme matrices, PFA matrix, and PFA 


\section{Appendix I.}

\section{Phosphorus Sparing Efficacy of diets containing Biostrong 510}

\section{Experimental Design}

10 treatments replicated 9 times

Male broilers will be given a pretest from $\mathrm{d} 1-\mathrm{d} 3$

On $\mathrm{d} 3$ birds will be individually weighed and allocated to pens so that beginning pen weight will not vary

Experimental treatments will be fed on $\mathrm{d} 3$

\begin{tabular}{|l|}
\hline Experimental Treatments \\
\hline 1. Basal diet @ $0.23 \% \mathrm{AP}$ and $0.8 \% \mathrm{Ca}^{\mathrm{a}}$ \\
\hline 2. Basal diet @ $0.28 \% \mathrm{AP}$ and $0.8 \% \mathrm{Ca}$ \\
\hline 3. Basal diet @ $0.33 \% \mathrm{AP}$ and $0.8 \% \mathrm{Ca}$ \\
\hline 4. Basal diet @ $0.38 \% \mathrm{AP}$ and $0.8 \% \mathrm{Ca}$ \\
\hline 5. Basal diet @ $0.23 \% \mathrm{AP}$ and $0.8 \% \mathrm{Ca}+$ phytase \\
\hline 6. Basal diet @ $0.23 \% \mathrm{AP}$ and $0.8 \% \mathrm{Ca}+$ Biostrong 510 \\
\hline 7. Basal diet @ $0.23 \% \mathrm{AP}$ and $0.8 \% \mathrm{Ca}+$ phytase + Biostrong 510 \\
\hline 8. Basal diet @ $0.28 \% \mathrm{AP}$ and $0.8 \% \mathrm{Ca}+$ phytase \\
\hline 9. Basal diet @ $0.28 \% \mathrm{AP}$ and $0.8 \% \mathrm{Ca}+$ Biostrong 510 \\
\hline 10.Basal diet @ $0.28 \% \mathrm{AP}$ and $0.8 \% \mathrm{Ca}+$ phytase + Biostrong 510 \\
\hline
\end{tabular}

${ }^{a}$ for all other nutrients formulation will meet Cobb Least Cost starter recommendations (no antibiotic).

\section{Feed Manufacture}

Diets will be fed in mash form.

Diets used for the standard curve will be created by manufacturing diet 1 and diet 2 as described above then blending diets to obtain diet 3 and 4. Diets 5, 6, 7, 8, 9, and 10 will come from adding product to the original diet 1 or diet 2 formulations. Phytase or Biostrong 510 will be added to a small $10 \mathrm{lb}$. allotment prior to being remixed with the total diet. Diet formulations will be similar to our past performance study.

\section{Bird Models}

Male Cobb 500 broiler chicks

\section{Experimental Unit}

One pen of 8, male Cobb 500 broilers 


\section{Variables Measured}

- Starter diets will be manufactured and analyzed for the following prior to feeding
a. Biostrong concentration
b. Calcium
c. Total Phosphorus

\section{Experimentation}

Broilers will be fed experimental diets from $\mathrm{d} 3$ to $\mathrm{d} 21$. Variables measured will include-
a. Live weight gain
b. Feed conversion ratio
c. Tibia ash
d. Available Phosphorus sparing effects can be calculated using assays a-c.
e. Apparent metabolizable energy, digestible $\mathrm{Ca}$, and digestible $\mathrm{P}$ will be estimated from total collection during d18-21.

\section{Budget}

Facility/Labor
a. NA

Feed and Feed Manufacture

a. Feed Manufacturing - $\$ 1,000$

b. Starter Feed -250 lbs./trt. minimum of 2,500 lbs of feed @ \$500/ton - $\$ 625$

Chick cost

a.750 chicks @ \$1.30 each - \$975

b. Transportation to and from commercial hatchery $\$ 300$

Laboratory Analysis

Prior to beginning the study

a. Total Phosphorus - 10 feed samples @ 17/sample - \$170.00

b. Total Calcium - 10 feed samples @ 17/sample - $\$ 170.00$

c. Shipping to Delacon - ?

AME, Digestible Ca and $\mathrm{P}$

a. 100 gross energy samples (feed and excreta) @ 36/sample - \$3,600

b. 90 calcium samples (excreta) @ 17/sample - $\$ 1,530$

c. 90 phosphorus samples (excreta) @ 17/sample - \$1,530

Shipping/Transportation

a. shipping of samples - $\$ 300.00$ 
Total - \$10,200.00 (plus shipping to Delacon for Biostrong analysis)

Total without the AME, Digestible Ca and $P$ work $=\$ 3,440$ (plus shipping to Delacon for Biostrong analysis) 
Appendix II. Matrix Value Justification of a Commercially Available Phytase

\section{Feed Manufacture:}

Twelve dietary treatments, formulated to meet JBS United recommendations, were manufactured at West Virginia University's pilot feed mill. Starter feed was formulated to meet Cobb Vantress Inc. least cost starter recommendations and fed for a pre-test period of seven days. The basal diet (Table 1), which totaled 348.98 lbs., was batched and divided into 12 aliquots with diet 1 totaling $26.43 \mathrm{lb}$, diet 2 totaling $27.53 \mathrm{lb}$, and diets 3 through 9 totaling $28.4 \mathrm{lb}$ each (Table 2).

Diets 1, 2, and 3 were formulated as the available phosphorus standard curve diets and contained $.10 \% \mathrm{aP}, .175 \% \mathrm{aP}$, and $.25 \% \mathrm{aP}$, respectively. Potassium phosphate $\left(\mathrm{KH}_{2} \mathrm{PO}_{4}\right)$ was incorporated into diets 2 and 3 at $.33 \%$ and $.66 \%$. Experimental phytase and corn starch were added prior to individual mixing in a Hobart style mixer for ten minutes.

\section{Broilers:}

A total of 200 male, Cobb 500 broilers were purchased from a commercial hatchery at hatch. One hundred ninety-two of these broilers were selected based on weight to create uniformity in initial pen weight. Weighing occurred on day eight and groups of selected birds were randomly allotted to 1 of 48 raised wire cages located in one, environmentally controlled room. Blocks of treatments were comprised of 12 adjacent cages housing 4 birds per cage. There were four blocks or replicates. Feed and water were provided ad libitum and birds received 24 hours of light per day. During the $1-7 \mathrm{~d}$ pre test period, birds were fed a nutritionally adequate starter diet 
that met Cobb Vantress Inc. least cost starter recommendations. On $\mathrm{d} 8$ each of the experimental diets were randomly assigned to cages within each block.

On d 21, birds were killed via cervical dislocation and final pen weight was obtained. The performance variables measured were beginning pen weight, ending bird weight, live weight gain, feed intake, feed conversion ratio, and mortality (Table 3). Left tibias were excised from

each bird, dried, defatted, and ashed at $600^{\circ} \mathrm{C}$ for 16 hours to determine percentage ash (Table 4).

\section{Statistical Analysis:}

Analyses were completed using GLM ANOVA procedure from the SAS Institute and when significant differences were detected, treatment means were separated and compared using Fisher's LSD. Regression analysis was performed using standard curve treatments in order to obtain formulas to calculate phosphorus sparing. 
Table 1. Basal Diet Formulation

Basal diet:

\begin{tabular}{lrrr} 
Ingredient & Working \% & g/batch & lbs \\
\hline Cornstarch & to 100 & & \\
Corn-finely ground & 51.400 & 82240.00 & 181.15 \\
SBM & 39.690 & 63504.00 & 139.88 \\
Soybean oil & 5.000 & 8000.00 & 17.62 \\
DL-Methionine & 0.200 & 320.00 & 0.70 \\
Limestone, ground & 1.670 & 2672.00 & 5.89 \\
Salt & 0.400 & 640.00 & 1.41 \\
Vitamin/Trace-mineral mix & 0.625 & 1000.00 & 2.20 \\
Bacitracin (BMD 60) & 0.038 & 60.80 & 0.13 \\
\hline & 99.023 & 158436.80 & 348.98
\end{tabular}


Table 2. Diet Formulations

\begin{tabular}{|c|c|c|c|c|c|}
\hline Treatment & Treatment & $\begin{array}{c}\text { Basal } \\
\text { Amount (g) }\end{array}$ & $\begin{array}{c}\mathrm{KH}_{2} \mathrm{PO}_{4} \\
(\mathrm{~g})\end{array}$ & $\begin{array}{l}\text { Corn Starch } \\
\text { as Filler (g) }\end{array}$ & $\begin{array}{c}\text { Treatment } \\
\text { Total }(g)\end{array}$ \\
\hline 1 & $\begin{array}{l}\text { P-deficient corn- } \\
\text { SBM basal diet } \\
(0.10 \% \text { aP })\end{array}$ & $11,882.760$ & N/A & 117.240 & 12,000 \\
\hline 2 & $\begin{array}{l}\text { As } 1+0.075 \% \mathrm{P} \\
(\mathrm{KH} 2 \mathrm{PO} 4)\end{array}$ & $12,377.875$ & 41.3 & 80.825 & 12,500 \\
\hline 3 & $\begin{array}{l}\text { As 1+0.150\% P } \\
\text { (KH2PO4) }\end{array}$ & $12,872.990$ & 85.903 & 41.107 & 13,000 \\
\hline
\end{tabular}

\begin{tabular}{|c|l|l|l|l|}
\hline Treatment & Treatment & $\begin{array}{l}\text { Phytase Inclusion } \\
\text { Rate(g) }\end{array}$ & $\begin{array}{l}\text { Basal Diet } \\
(\mathbf{g})\end{array}$ & $\begin{array}{l}\text { Corn Starch } \\
(\mathbf{g})\end{array}$ \\
\hline 4 & LF\#1 @250 U/kg & .418 & $12,872.990$ & 126.592 \\
\hline 5 & LF\#2@250 U/kg & .450 & $12,872.990$ & 126.56 \\
\hline 6 & LF\#3@250 U/kg & .432 & $12,872.990$ & 126.578 \\
\hline 7 & LF\#4@250 U/kg & .392 & $12,872.990$ & 126.618 \\
\hline 8 & LF\#4@500 U/kg & .785 & $12,872.990$ & 126.225 \\
\hline 9 & $11805 @ 250 \mathrm{U} / \mathrm{kg}$ & .288 & $12,872.990$ & 126.722 \\
\hline 10 & $11803 @ 250 \mathrm{U} / \mathrm{kg}$ & .291 & $12,872.990$ & 126.719 \\
\hline 11 & Standard@250 U/kg & 1.429 & $12,872.990$ & 125.581 \\
\hline 12 & $\begin{array}{l}\text { PF OL 23692@ } \\
\text { U/kg }\end{array}$ & .746 & $12,872.990$ & 126.264 \\
\hline
\end{tabular}


Table 3. Broiler Performance

\begin{tabular}{|c|c|c|c|c|c|c|c|c|}
\hline Treatment & $\begin{array}{c}\text { Beginning Pen } \\
\text { weight (kg) }\end{array}$ & $\begin{array}{c}\text { Ending Bird } \\
\text { Weight (kg) }\end{array}$ & Feed Intake (kg) & $\begin{array}{c}\text { Live Weight Gain } \\
(\mathbf{k g})\end{array}$ & $\begin{array}{c}\text { Feed Conversion } \\
\text { Ratio }(\mathbf{k g} / \mathbf{k g})\end{array}$ & $\begin{array}{c}\text { Mortality } \\
(\%)\end{array}$ & $\begin{array}{c}\text { Tibia } \\
\text { Ash }(\%)\end{array}$ & $\begin{array}{c}\text { Mg } \\
\text { ash/chick }\end{array}$ \\
\hline 1 & 0.535 & $0.443^{\mathrm{e}}$ & $1.912^{\mathrm{e}}$ & $.275^{\mathrm{f}}$ & $1.78^{\mathrm{f}}$ & $18.75^{\mathrm{b}}$ & $20.20^{\mathrm{g}}$ & $308^{\mathrm{h}}$ \\
\hline 2 & 0.536 & $0.603^{\mathrm{c}}$ & $2.815^{\mathrm{b}}$ & $.469^{\mathrm{bc}}$ & $1.50^{\mathrm{abcd}}$ & 0 & $26.99^{\mathrm{b}}$ & $549^{\mathrm{bc}}$ \\
\hline 3 & 0.532 & $0.676^{\mathrm{a}}$ & $3.171^{\mathrm{a}}$ & $.543^{\mathrm{a}}$ & $1.46^{\mathrm{a}}$ & 0 & $32.39^{\mathrm{a}}$ & $764^{a}$ \\
\hline 4 & 0.533 & $0.513^{\text {de }}$ & $2.390^{\text {cd }}$ & $.379^{\mathrm{de}}$ & $1.58^{\mathrm{bcd}}$ & 0 & $21.82^{\mathrm{fg}}$ & $409^{\mathrm{fg}}$ \\
\hline 5 & 0.538 & $0.510^{\mathrm{de}}$ & $2.379^{\text {cd }}$ & $.367^{\mathrm{de}}$ & $1.62^{\mathrm{e}}$ & 0 & $21.65^{\mathrm{fg}}$ & $391^{\mathrm{fg}}$ \\
\hline 6 & 0.522 & $0.601^{\mathrm{c}}$ & $2.588^{\mathrm{c}}$ & $.460^{\mathrm{bc}}$ & $1.57^{\text {bcde }}$ & 6.25 & $24.36^{\mathrm{de}}$ & $443^{\text {efg }}$ \\
\hline 7 & 0.533 & $0.470^{\mathrm{e}}$ & $2.295^{\mathrm{d}}$ & $.336^{\mathrm{ef}}$ & $1.72^{\mathrm{f}}$ & 0 & $21.40^{\mathrm{fg}}$ & $381^{\text {gh }}$ \\
\hline 8 & 0.544 & $0.548^{\text {cd }}$ & $2.565^{\mathrm{c}}$ & $.412^{\mathrm{cd}}$ & $1.56^{\text {bcde }}$ & 0 & $24.67^{\mathrm{de}}$ & $459^{\text {def }}$ \\
\hline 9 & 0.533 & $0.552^{\text {cd }}$ & $2.517^{\mathrm{c}}$ & $.408^{\text {cde }}$ & $1.60^{\mathrm{de}}$ & 6.25 & $23.06^{\mathrm{ef}}$ & $446^{\text {efg }}$ \\
\hline 10 & 0.535 & $0.651^{\mathrm{a}}$ & $2.933^{\mathrm{b}}$ & $.517^{\mathrm{ab}}$ & $1.55^{\text {abcde }}$ & 0 & $24.78^{\text {cde }}$ & $531^{\text {cd }}$ \\
\hline 11 & 0.538 & $0.635^{\mathrm{a}}$ & $2.962^{\mathrm{ab}}$ & $.500^{\mathrm{ab}}$ & $1.48^{\mathrm{ab}}$ & 0 & $26.72^{\mathrm{bc}}$ & $621^{\mathrm{b}}$ \\
\hline 12 & 0.525 & $0.619^{\mathrm{abc}}$ & $2.908^{\mathrm{b}}$ & $.487^{\mathrm{ab}}$ & $1.49^{\mathrm{abc}}$ & 0 & $25.17^{\mathrm{bcd}}$ & $505^{\text {cde }}$ \\
\hline ANOVA P value & 0.116 & $<0.0001$ & $<0.0001$ & $<0.0001$ & $<0.0001$ & 0.0038 & $<0.0001$ & $<0.0001$ \\
\hline $\mathrm{LSD}^{1}$ & & 0.0729 & 0.2117 & 0.0727 & 0.0942 & & 2.0228 & 72.758 \\
\hline
\end{tabular}

${ }^{\mathrm{a}-\mathrm{f}}$ Means within a column without a common superscript differ $(\mathrm{P} \leq .0 .05)$

1 Fishers Least Significant Difference 
Table 4. Calculated Phytase Sparing Effects

\begin{tabular}{|c|c|c|c|c|}
\hline Ending Bird Weight (kg) & TRT & Mean & Calculated aP & Sparing Effect \\
\hline Slope $=1.55481$ & 4 & 0.51256 & 0.135656447 & 0.035656447 \\
\hline \multirow[t]{8}{*}{ Intercept $=.30164$} & 5 & 0.50122 & 0.128362951 & 0.028362951 \\
\hline & 6 & 0.6012 & 0.192666628 & 0.092666628 \\
\hline & 7 & 0.46497 & 0.105048205 & 0.005048205 \\
\hline & 8 & 0.54771 & 0.158263711 & 0.058263711 \\
\hline & 9 & 0.55187 & 0.160939279 & 0.060939279 \\
\hline & 10 & 0.65091 & 0.22463838 & 0.12463838 \\
\hline & 11 & 0.63446 & 0.214058309 & 0.114058309 \\
\hline & 12 & 0.61859 & 0.203851274 & 0.103851274 \\
\hline Live Weight Gain (kg) & TRT & Mean & Calculated aP & Sparing Effect \\
\hline Slope $=1.78497$ & 4 & 0.37923 & 0.147178944 & 0.047178944 \\
\hline \multirow[t]{8}{*}{ Intercept $=.11652$} & 5 & 0.36673 & 0.140176025 & 0.040176025 \\
\hline & 6 & 0.45993 & 0.192389788 & 0.092389788 \\
\hline & 7 & 0.33615 & 0.123044085 & 0.023044085 \\
\hline & 8 & 0.41175 & 0.165397738 & 0.065397738 \\
\hline & 9 & 0.40761 & 0.163078371 & 0.063078371 \\
\hline & 10 & 0.51726 & 0.224507975 & 0.124507975 \\
\hline & 11 & 0.50006 & 0.214871959 & 0.114871959 \\
\hline & 12 & 0.48725 & 0.207695367 & 0.107695367 \\
\hline Feed Conversion & TRT & Mean & Calculated aP & Sparing Effect \\
\hline Slope $=1.96006$ & 4 & 1.57691 & 0.177743861 & 0.077743861 \\
\hline \multirow[t]{8}{*}{ Intercept $=-2.15563$} & 5 & 1.6232 & 0.156269861 & 0.056269861 \\
\hline & 6 & 1.56934 & 0.181255596 & 0.081255596 \\
\hline & 7 & 1.72217 & 0.110357529 & 0.010357529 \\
\hline & 8 & 1.55969 & 0.185732245 & 0.085732245 \\
\hline & 9 & 1.59543 & 0.169152406 & 0.069152406 \\
\hline & 10 & 1.54916 & 0.190617128 & 0.090617128 \\
\hline & 11 & 1.48201 & 0.221768114 & 0.121768114 \\
\hline & 12 & 1.49301 & 0.216665198 & 0.116665198 \\
\hline
\end{tabular}




\begin{tabular}{|l|r|r|l|l|}
\hline Tibia Ash & & & & \\
\hline Slope= 81.25 & TRT & \multicolumn{1}{l|}{ Mean } & Calculated aP & Sparing Effect \\
\hline Intercept=12.309 & 4 & 21.82 & 0.117058462 & 0.017058462 \\
\hline & 5 & 21.65 & 0.114966154 & 0.014966154 \\
\hline & 6 & 24.36 & 0.14832 & 0.04832 \\
\hline & 7 & 21.4 & 0.111889231 & 0.011889231 \\
\hline & 8 & 24.67 & 0.152135385 & 0.052135385 \\
\hline & 9 & 23.06 & 0.13232 & 0.03232 \\
\hline & 10 & 24.78 & 0.153489231 & 0.053489231 \\
\hline & 11 & 26.72 & 0.177366154 & 0.077366154 \\
\hline & 12 & 25.17 & 0.158289231 & 0.058289231 \\
\hline Mg ash/chick & & & & \\
\hline Slope=3037.5 & TRT & Mean & Calculated aP & Sparing Effect \\
\hline Intercept=8.65 & 4 & 409 & 0.131802469 & 0.031802469 \\
\hline & 5 & 391 & 0.125876543 & 0.025876543 \\
\hline & 6 & 443 & 0.142995885 & 0.042995885 \\
\hline & 7 & 381 & 0.122584362 & 0.022584362 \\
\hline & 8 & 459 & 0.148263374 & 0.048263374 \\
\hline & 9 & 446 & 0.143983539 & 0.043983539 \\
\hline & 10 & 531 & 0.171967078 & 0.071967078 \\
\hline & 11 & 621 & 0.201596708 & 0.101596708 \\
\hline & 12 & 505 & 0.163407407 & 0.063407407 \\
\hline
\end{tabular}




\title{
Laurel Shires
}

1worley@mix.wvu.edu

270 Sine Place

Bruceton Mills, WV 26525

(304) 676-7880

\section{Education:}

West Virginia University, Morgantown WV

Aug. 2010

Masters of Science Animal Nutrition

GPA: $3.5 / 4.0$

West Virginia University, Morgantown WV

May 2008

Bachelor of Agricultural Sciences

Major: Animal and Nutritional Sciences

Minor: Horticultural Studies

Major GPA: 4.0/4.0

Cumulative GPA: 3.6/4.0

\section{Experience:}

\author{
West Virginia University, Morgantown WV August 2008-Present \\ Graduate Research Assistant \\ - Feed production, WVU Feed Mill \\ - Feed Formulation \\ - Proximate Analysis \\ - Tibia Ash \\ - Assisting in Multiple Research Studies \\ - Teaching Aid for Poultry Science Labs \\ - Teaching Assistant for Collegiate Poultry Judging
}

USDA-ARS, Beaver WV

May 2006-August 2008

Biological Sciences Aide

- Basic Animal Husbandry

- Fecal Egg Counts

- Packed Cell Volume Counts

- Crude Fiber Analysis of Forage Grasses

- Vaccinations, De-worming and Blood Draws 
- Basic Fertilizer Application Calculations

Dairy Queen, Fairlea WV

June 2002-Decemeber 2006

Shift Manager

- Daily Engagement with Customers and Public

- Managed Multiple Employees

- Performed Inventory Tasks

- Responsible for Multiple Financial Tasks

Coursework: I have completed the following animal science related courses: Introduction to Animal Science, Companion Animal Science, Introduction to Animal Nutrition, as well as Ruminant Nutrition, Non-ruminant Nutrition, Poultry Production, Animal Physiology, Animal Parasitology, Nutritional Biochemistry, Calving Management, and Collegiate Poultry Judging.

Projects: USDA-ARS Projects:

- "Plant Materials for Control of Gastrointestinal Parasites in Small Ruminants"

- "Meat Goat Finishing Systems for Appalachian Small Farms"

- "Medicinal Botanical Production and Processing"

- "Native Plant Resources for Small Ruminant Production in Appalachia".

\section{Graduate Projects:}

- West Virginia University Poultry Research Presentation-West Virginia State Fair

- "Justifying phytogenic feed additive matrix values in conjunction with exogenous feed enzymes".

- "Modeling the effects of high pellet quality on broiler growth and carcass quality".

- "Increasing mixer-added fat improves exogenous enzyme efficacy and broiler performance".

- "Examining the relationship between pellet quality, broiler performance and bird sex".

- "Thermostability and efficacy of exogenous feed enzymes".

Skills:

Computer: Microsoft Office, Brill Feed Formulation Program, Taurus Beef Cattle Ration Formulation and Evaluation Software, R Statistical Software, Alphanumeric Entry of 65 wpm.

Personal: Certified in CPR and First Aid, Certification in Avian Influenza Task Force Training, Multiple presentations at National meetings, Feed 
conversion ratios and other calculations, Driven, Hard Working, and Cooperative

Achievements: $\quad$ Promise Scholar

Magna Cum Laude graduate.

Activities: $\quad$ Poultry Science Journal Club

Gamma Sigma Delta

Collegiate Poultry Judging Coach

Research assistant to VA Poultry Grower's Co-op

Poultry Science Association 